\title{
Geochemical and mineralogical reactions driven by acid generation and metal release from pyritic wastes improperly disposed on estuarine marsh soils
}

MIHAELA M. GRANTCHAROVA, MA AND JUAN CARLOS FERNANDEZ-CALIANI

University of Huelva

Presenting Author: mmgrantch@gmail.com

Leaching and release of hazardous contaminants from improperly disposed wastes can lead to soil and water pollution, thus posing risks to ecological and human receptors. This is of particular concern in coastal wetlands heavily impacted by mining and industrial activities such as the salt marshes of the Odiel river (Huelva), a UNESCO biosphere reserve on the southwest coast of Spain. Past mineral-processing operations developed for over a century have left a legacy of huge amounts of pyrite concentrates stockpiled on the riverbank, leading to significant environmental degradation. With the aim of addressing this issue, a total of 48 soil samples were collected up to a depth of $60 \mathrm{~cm}$ in 13 sites along two parallel transects extending about $200 \mathrm{~m}$ from the abandoned stockpiles to the adjacent estuarine marsh soils. As a result of acid generation and heavy metal release by oxidative weathering of pyrite, the soil in close proximity to the wastes has ultra-acidic $\mathrm{pH}$ values and retains extremely high concentrations of $\mathrm{Pb}\left(9838 \mathrm{mg} \mathrm{kg}^{-1}\right)$, As (1538 mg kg $\left.{ }^{-1}\right), \mathrm{Zn}\left(1486 \mathrm{mg} \mathrm{kg}^{-1}\right), \mathrm{Cu}\left(705 \mathrm{mg} \mathrm{kg}^{-1}\right), \mathrm{Sb}$ (397 $\left.\mathrm{mg} \mathrm{kg}{ }^{-1}\right)$, $\mathrm{Tl}\left(23.2 \mathrm{mg} \mathrm{kg}^{-1}\right)$, and $\mathrm{Cd}\left(4.9 \mathrm{mg} \mathrm{kg}^{-1}\right)$ bound to a suite of secondary minerals with a wide range in solubility. Formation of epitaxial overgrowths of anglesite on barite, and less soluble jarosite-group minerals play an important role in attenuation of trace elements, notably $\mathrm{Pb}, \mathrm{As}$ and $\mathrm{Tl}$. During dry periods, acid-sulfate solutions migrate to the soil surface by capillary action forming efflorescent crusts of highly soluble sulfate minerals (melanterite, szomolnokite, coquimbite, copiapite, halotrichite, epsomite and hexahidrite, depending on water activity and redox conditions), which act as transient sinks for metals, particularly $\mathrm{Cu}$ and $\mathrm{Zn}$. In distal locations $(>120 \mathrm{~m}$ away from the source of sulfide oxidation), the soil becomes moderately acidic with $\mathrm{pH}$ ranging from 5 and 6.3 , leading to the formation of $\mathrm{Fe}$ (III) oxyhydroxides. In most distal samples, trace element concentrations fall within the local baseline range for marsh soils, suggesting that natural attenuation processes are occurring by a series of mineralogical transformations involving oxidation, dehydration, and neutralization reactions. 